\title{
Lumen
}

Selected Proceedings from the Canadian Society for Eighteenth-Century Studies

\section{Cook and the Cannibals: Nootka Sound, 1778}

\section{Noel Elizabeth Currie}

Volume 13, 1994

URI : https://id.erudit.org/iderudit/1012522ar

DOI : https://doi.org/10.7202/1012522ar

Aller au sommaire du numéro

Éditeur(s)

Canadian Society for Eighteenth-Century Studies / Société canadienne d'étude du dix-huitième siècle

ISSN

1209-3696 (imprimé)

1927-8284 (numérique)

Découvrir la revue

Citer cet article

Currie, N. E. (1994). Cook and the Cannibals: Nootka Sound, 1778. Lumen, 13,

71-78. https://doi.org/10.7202/1012522ar d'utilisation que vous pouvez consulter en ligne.

https://apropos.erudit.org/fr/usagers/politique-dutilisation/ 


\section{Cook and the Cannibals: Nootka Sound, 1778}

Reading the official 1784 edition of the journals of Captain James Cook's third Pacific voyage gives the impression that Cook's party encountered one group of cannibals after another. ${ }^{1}$ European readers of the time eagerly consumed such reports of cannibalism and assumed their veracity. With the benefit of hindsight, however, we can identify cannibalism as a trope characteristic of the exploration and discovery genre; writers who were familiar with this trope in the works of Herodotus, Mandeville, and Columbus (to mention a few standards ${ }^{2}$ ) reinscribed it. Cook appears to have been among them: just as his journals reveal the influence of the cannibal trope, so they influenced subsequent writers in their turn.

Not all of Cook's cannibals were to be found in the South Pacific. In the spring of 1778 , the party of his third voyage spent a month at a place that is now known (as a result of that visit) as Nootka Sound on the west coast of Vancouver Island. Although Cook's party met another cultural group across the beach, history has presented us with one perspective on this encounter only: that of Cook, whose 1784 journal defines the Natives of Nootka Sound by using the cannibal trope. Like the officers and crewmen under him, Cook read the northwest coast of North America through a double filter, using both the perceptual tools of Europe and those formed over the course of his naval experience in the South Pacific. However, it is necessary to differentiate between Cook and his journals, or between the tropes produced by Cook and the tropes of Cook produced by editors and historians, since J.C. Beaglehole's 1967 scholarly edition of the journals indicates that Cook himself did not ascribe cannibalism to the Nootka. ${ }^{3}$ The account of the month at Nootka Sound, then, reveals how the already well-established European discourse of cannibalism in so-called savage lands lent itself to the appropriation of those lands from peoples identified as cannibals.

My analysis of cannibalism as a trope is heavily indebted to the work of Walter Arens, who questions 'not why people eat human flesh, but why one group invariably assumes that others do. ${ }^{4}$ Arens treats cannibalism as a discursive rather than as a gustatory practice, particularly 
given the fact that many famous cannibals, such as the Tupinamba of South America, 'who were supposed to make others disappear into their cooking pots, have instead themselves vanished.... Although there may be some legitimate reservations about who ate whom, there can be no question of who exterminated whom. ${ }^{5}$ Arens's attempt to debunk the myth of cannibalism as a prevalent cultural feature has been challenged by anthropologist Peggy Reeves Sanday, who treats cannibalism as a physical act which has cultural and symbolic meanings. ${ }^{6}$ However, Sanday does not discuss the Christian mass - in which the bread and wine of the Eucharist are transformed for the faithful into the body and blood of Christ - as an example of a cannibal ritual, even metaphorically. Instead she develops her analysis of cannibalism through examples from non-European cultures only, arguably proving Arens's point that Europeans have used the charge of cannibalism to deny the humanity of other, mostly non-European groups, by default. The discrepancy between European claims of cannibalism in indigenous peoples and the historical consequences of contact (especially when history is written by the conquerors) suggests that in travel and exploration literature in general and in Cook's journals in particular cannibalism is not a matter of simple observation, but instead functions as a discourse to justify colonial or imperial appropriation.

The official edition of Cook's third voyage was edited by Dr. Douglas, Bishop of Salisbury, commissioned by the Lords of the Admiralty, and published in 1784. Comparing specific passages from Douglas's edition with comparable moments in Beaglehole's scholarly edition reveals the difference between what I have called the tropes produced by Cook and the tropes of Cook produced by others. For example, Douglas's edition describes the first trade encounter between the Europeans and the Nootka thus:

The articles which they offered to sale were skins... weapons... fish-hooks, and instruments of various kinds; wooden vizors of many different monstrous figures; a sort of woollen stuff, or blanketing; bags filled with red ochre; pieces of carved work; beads; and several other little ornaments of thin brass and iron, shaped like a horse-shoe, which they hang at their noses; and several chissels [sic], or pieces of iron, fixed to handles. From their possessing which metals, we could infer that they had either been visited before by some civilized nation, or had connections with other tribes on their continent, who had communication with them. But the most extraordinary of all the articles which they brought to the ships for sale, were human skulls, and hands not quite stripped of the flesh, which they made our people plainly understand they had eaten; and, indeed, some of them had evident marks that they had been upon the fire. We had but too much reason to suspect, from this circumstance, that the horrid practice of feeding on 
their enemies is as prevalent here, as we had found it to be at New Zealand and other South Sea islands. For various articles which they brought, they took in exchange knives, chissels, pieces of iron and tin nails, looking glasses, buttons, or any kind of metal. Glass beads they were not fond of and cloth of every sort they rejected. ${ }^{7}$

Beaglehole's scholarly edition of 1967, however, records this moment in Cook's journal in a rather less sensational way:

Their articles [for trade] were the Skins of various animals... Weapons... pieces of carved work and even human skuls [sic] and hands, and a variety of little articles too tedious to mention. For these they took in exchange, Knives, chisels, pieces of iron \& Tin, Nails, Buttons, or any kind of metal. Beads they were not fond of and cloth of all kinds they rejected. ${ }^{8}$

One significant difference between these two passages is that Beaglehole's version - based on Cook's logs and journals only - is much shorter, primarily because Douglas lists what Beaglehole records as 'a variety of little articles too tedious to mention.' Another glaring discrepancy between the two texts is that although Cook does not ascribe cannibalism to the Nootka, Douglas (a ghostwriter whose name does not appear on the title page) does, using Cook's authority to record Nootkan trade goods as evidence of cannibalism among them.

Of course, first-person narration is another trope of the exploration and discovery genre, which Douglas exploits to establish the truth-claim of eyewitness testimony when in fact he alters or 'edits' the text quite radically. Douglas's use of such rhetorical devices as litotes, a form of understatement in which something is said by denying its opposite, gives the hardworking navigator the air of a gentleman on the Grand Tour. ${ }^{9}$ For example, Cook's description of the manner of preserving fish at Nootka Sound, and the result, appears in Beaglehole thus:

They hang them on small rods at first about a foot from the fire, afterwards they remove them higher and higher to make room for others till they get to the roof of the house; when dryed they are made up into bales and covered with Mats; thus they are kept till wanting and eat very well, but there is but little meat upon them. In the same manner they cure Cod and other large fish, and some are cured in the air without fire. ${ }^{10}$

In Douglas's edition the same passage is virtually identical, except for one phrase:

They hang them on small rods, at first about a foot from the fire; afterward they remove them higher and higher, to make room for others, till the rods, on which 
the fish hang, reach the top of the house. When they are completely dried, they are taken down and packed close in bales, which they cover with mats. Thus they are kept till wanted; and they are not a disagreeable article of food. Cod, and other large fish, are also cured in the same manner by them; though they sometimes dry those in the open air, without fire. ${ }^{11}$

Fish which for Cook 'eat very well, but there is but little meat upon them' are transformed by Douglas into 'not a disagreeable article of food': a Captain's prosaic concern with provisioning his crew as efficiently (and in Cook's case as healthfully) as possible is recast as a mini-meditation on the pleasures of the table. In Douglas's edition of the journal, litotes establishes the qualities of gentility and discernment deemed essential in a Cook who was carefully being constructed, in James A. Williamson's phrase, as 'the representative not only of England but of civilization.... ${ }^{12}$ The plain-speaking Cook of the log-books and journals is elevated to an imperial hero.

While considering the use and effect of rhetoric in Cook's journal, it is worth mentioning that western humanism has traditionally assumed a written language to be the external marker of civilization. The rhetorical figures that Douglas puts in Cook's mouth highlight the hierarchical nature of Cook's relationship with these (or any other) Natives. The contrast between the monuments of western civilization, personified by Cook, and the dumbshow of primitive culture - unintelligible and (or perhaps because) illegible - demonstrates European superiority to a European audience. Douglas's editing establishes and ensures the distance between a Native 'them' ('homogenized into a collective "they" and a European 'us.'

Douglas's edition of the journal (a composite text which borrowed liberally from the accounts of the other officers without necessarily acknowledging them) presents a Cook who ascribes cannibalism to the Nootka. Beaglehole's scholarly edition (which adds pertinent information from the other officers' journals in the form of footnotes) presents a Cook who does not. This discrepancy indicates at least the possibility that cannibalism operates as a discourse rather than as anserved behaviour within the encounter. The discourse of cannibalism is also at work in Beaglehole's edition, however, when he discusses the issue in a footnote (much too long to quote here), despite the fact that Cook mentions neither the word nor the practice. ${ }^{14}$ Significantly, this footnote takes up more space on the page than the passage it ostensibly annotates. Beaglehole splices one comment by Cook (not on cannibalism) together with some comments on cannibalism from the other officers' journals; the words of the other officers occupy a great deal more space in the footnote than do Cook's. As if this were not enough, the footnote ends 
with commentary from twentieth-century historians and anthropologists on the issue of Nootkan cannibalism. By giving the footnoted discussion more space than Cook's text, which does not even mention the practice, Beaglehole's edition reinscribes cannibalism as a matter worthy of scholarly consideration.

Beaglehole's footnote represents in miniature the development of the 'story' of Nootkan cannibalism. Although this story has been attributed to Cook, Beaglehole's edition of the text of the journal reveals that Cook was not in fact the source. In effect, Douglas has put words from the accounts of the other officers into Cook's mouth. ${ }^{15}$ The account of the American marine corporal John Ledyard, independently published in the United States in 1783, makes the most explicit claim for cannibalism - not only among the Nootka. He records that many of the crew partook of a cannibal feast, 'a human arm roasted': 'I have heard it remarked that human flesh is the most delicious, and therefore tasted a bit, and so did many others without swallowing the meat or the juices, but either my conscience or my taste rendered it very odious to me. ${ }^{16}$ Apparently, not finding the meat 'delicious' is enough to disqualify the Europeans from the ranks of the cannibal savages, even though Ledyard's account 'proved absolutely nothing about the Nootka and identified only one known cannibal - Ledyard himself! ${ }^{17}$ Other officers, a little more critically minded or perhaps not counting on book sales, refused to make a judgment on the subject of Nootkan cannibalism. ${ }^{18}$ But most of the journals of Cook's subordinates were not published until recently, many of them in Beaglehole's two-volume scholarly edition of the third voyage. ${ }^{19}$

In the same year that the official edition of Cook's journal was published, another appeared, claiming to be 'a copious, comprehensive, and satisfactory Abridgment' published by John Stockdale, Scatcherd and Whitaker, John Fielding, and John Hardy. ${ }^{20}$ If Douglas implied that the Nootka were cannibals, this later 1784 edition presents Nootkan cannibalism as a fact. At a point in his edition which corresponds (roughly) to parallel observations from Cook's journal in Douglas and Beaglehole's editions, Stockdale's Cook states:

Among all the articles, however, which they exposed to sale, the most extraordinary were human skulls, and hands, with some of the flesh remaining on them, which they acknowledged they had been feeding on; and some of them, indeed, bore evident marks of having been upon the fire. From this circumstance, it was but too apparent, that the horrid practice of devouring their enemies, is practiced here, as much as at New-Zealand, and other South-sea islands. ${ }^{21}$ 
No longer is cannibalism merely suspected, as in Douglas's edition: Stockdale's edition declares that the Nootka are so depraved as to readily acknowledge that they devour their enemies (in contrast to Douglas's relatively neutral 'feeding on'). By the end of 1784, the savages of the Pacific are served up for European consumption as cannibals one and all.

Douglas's phrase 'we had but too much reason to suspect that the horrid practice of feeding on their enemies, is as prevalent here, as we had found it to be at New Zealand' acquired the status of historical truth in less than one year. Beaglehole's footnoted discussion of cannibalism makes clear by its inclusion of twentieth-century scholarly comment on the subject that Nootkan cannibalism is one ghostly assumption that remains to be definitively laid to rest. However, it was not inevitable that Europeans identify cannibalism as a Nootkan practice. Archer notes that the Spaniards who first made contact with coastal societies in 1774, and who 'traditionally employed ethnological research and data collection for the end of eventual religious conversion,' make no mention of cannibalism until after reading Cook's published journal, which 'became the authoritative handbook for all who would navigate in the North Pacific and contact the Northwest Coast inhabitants. ${ }^{22}$ Whether or not the Nootka actually were cannibals is immaterial (to scholars, if not to the peoples whose realities have been shaped by the charge and the savagery it implies). Douglas recorded the suspicion of Nootkan cannibalism in his edition of Cook's Journal in such a manner as to inscribe both doubt and certainty, invoking all the authority of expertise gained by Cook in two previous voyages around the world among people for whom, Douglas says, the 'horrid practice... is prevalent.' Douglas gave the label to the peoples of the northwest coast, and it stuck.

The first English fur-trading vessel arrived at Nootka Sound one year after Cook's official journal was published, lured by reports of the huge profits to be made selling Nootka Sound furs in China. The motives of later writers and publishers, particularly of traders' accounts, and the ways their interests could be served by perpetuating the idea of Nootkan cannibalism, must also be considered. As in the Stockdale edition of 1784, cannibalism served as a sensational hook, a marketing technique to increase book sales. As well, fur-traders' tales of unimaginable ferocity and savagery among native trading partners functioned 'either to deter the more fainthearted competitors from entering their prime sea-otter preserves or to keep their bored and sometimes mutinous crews from deserting to live with the Indians. ${ }^{23}$ As a racial - and racist - discourse, cannibalism was motivated by the desire for economic profit and social control. It is this account of Nootkan cannibalism, attributed to Cook by Douglas, and maintained and perpetuated by later writers, which passed 
into European knowledge of the northwest coast. And it is this account of Nootkan cannibalism which provided an ideological justification for claiming European possession of the land and - in the name of civilization - for dispossessing its original inhabitants.

\section{NOEL ELIZABETH CURRIE \\ Vancouver, British Columbia}

\section{Notes}

1 James Cook, A Voyage to the Pacific Ocean. Undertaken, by the Command of His Majesty, for making Discoveries in the Northern Hemisphere... [ed. Bishop Douglas] 3 vols. (London, 1784). Further references to this work will be cited as Douglas.

2 See Herodotus, The Histories (5th-c. B.C.E.), trans. David Grene (Chicago: University of Chicago Press, 1987); The Travels of Sir John Mandeville, trans. C.W.R.D. Moseley (London: Penguin, 1983); and the Letter of Columbus in L.C. Jane, ed., Select Documents Illustrating the Four Voyages of Columbus, including those contained in R.H. Major's Select Letters of Christopher Columbus, vol. 1 of 2 (London: Hakluyt Society, 1930-32).

3 J.C. Beaglehole, ed., The Voyage of the Resolution and Discovery 1776-1780, Part 1 of 2. Vol. 3 of The Journals of Captain James Cook on his Voyages of Discovery, ed. J.C. Beaglehole, 3 vols. in 4, Hakluyt Society Extra Series no. 26 (Cambridge: Cambridge University Press, 1967). Further references to this work will be cited as Beaglehole III.i.

4 Walter Arens, The Man-Eating Myth: Anthropology and Anthropophagy (New York: Oxford University Press, 1979), p. 139; see also Olive Patricia Dickason, The Myth of the Savage and the Beginning of French Colonialism in the Americas (Edmonton: University of Alberta Press, 1984).

5 Arens, p. 31.

6 Peggy Reeves Sanday, Divine Hunger: Cannibalism as a Cultural System (New York: Cambridge University Press, 1986).

7 Douglas, II, 270-1, my emphasis.

8 Beaglehole, III.i, 296-7.

9 I.S. MacLaren, 'Inscribing the Empire: The Role of the Editor and Publisher in the Literature and Art of Nineteenth-Century Arctic Exploration,' paper presented at the Vancouver Conference on Exploration and Discovery, Simon Fraser University, Vancouver, B.C., 26 April 1992.

10 Beaglehole, III.i, 303-4, my emphasis.

11 Douglas, II, 280, my emphasis.

12 Quoted in John Lawrence Abbott, John Hawkesworth, Eighteenth-Century Man of Letters (Madison, Wisconsin: University of Wisconsin Press, 1982), p. 139. 
13 Mary Louise Pratt, 'Scratches on the Face of the Country; or, What Mr. Barrow Saw in the Land of the Bushmen' in 'Race,' Writing, and Difference, ed. Henry Louis Gates, Jr. (Chicago: University of Chicago Press, 1985), p. 139.

14 Beaglehole, III.i, 297.

15 One of the two officers cited in the footnote, Bayly, believed that the Nootka were cannibals: 'We bought 3 or 4 Human Hands which they brought to sell... they made signs that they were good eating, \& seemed to sell them us for that purpose or at least all of us understood them in that light' (Beaglehole, III.i, 297). However, the other, Edgar, 'bought a hand from one man... and then desir'd him to Eat it, which he would not do, I then offered him more Iron \& Brass than wou'd have purchased one of their most Elegant dresses, if he would eat part of it, all which offers he treated with Great Contempt I departed in Great anger...' (Beaglehole, III.i, 297).

16 John Ledyard, A Journal of Captain Cook's Last Voyage to the Pacific Ocean (Hartford, CT, 1783), p. 73.

17 Christon I. Archer, 'Cannibalism in the Early History of the Northwest Coast: Enduring Myths and Neglected Realities' (Canadian Historical Review 61 [4] 1980: 453-79), p. 463.

18 See J.C. Beaglehole, ed., Appendix III: Extracts from Officers' Journals, The Voyage of the Resolution and Discovery 1776-1780 Part 2, vol. 3 of The Journals of Captain James Cook on His Voyages of Discovery, 3 vols. in 4, Hakluyt Society Extra Series no. 36 (Cambridge: Cambridge University Press, 1967). Lieutenant James King writes, 'as we cannot be said to converse with the people, we can only judge from outward actions, \& not knowing all the Causes that give rise to them, we must be constantly led into error' (Beaglehole III.ii, 1406). Similarly, the surgeon David Samwell records 'we were led to think that these People are Cannibals, however of this we had no certain proof' (Beaglehole III.ii, 1092).

19 Archer, p. 463.

20 James Cook, A Voyage to the Pacific Ocean.... [abridged ed.], 3 vols. (London, printed for John Stockdale, Scatcherd \& Whitaker, John Fielding, and John Hardy, 1784). Further references to this work will be cited as Stockdale.

21 Stockdale, II, 211, my emphasis.

22 Archer, pp. 461-2.

23 Archer, p. 465. 